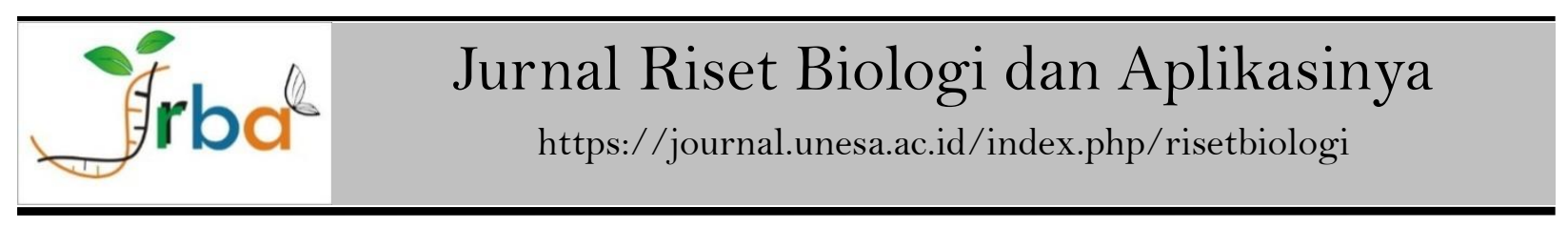

\title{
Screening of Extracellular Enzymes on Serratia marcescens strain MBC1
}

\author{
Meishy Handerlin Putri*, Kusuma Handayani, Wawan A. Setiawan, Berliana Damayanti, Cindy Lukyta \\ Ratih, Achmad Arifiyanto \\ Biology Departement, Faculty of Mathematics and Natural Sciences, Lampung University \\ Jln. Prof Soemantri Brojonegoro 1, Rajabasa District, Bandar Lampung, Lampung 35144, Indonesia \\ *Corresponding Author: \\ e-mail: handerlinmeishy@gmail.com
}

\section{Article History \\ Received Revised \\ Approved \\ Published}

\section{Keywords}

Hydrolase enzymes; Serratia marcescens strain MBC1; enzymatic activity

\begin{abstract}
Hydrolase enzymes are a class of enzymes used to break down the organic substrates into simpler molecules. Hydrolase enzymes play a role in biocontrol, industry, and public health. One of the hydrolase enzyme producers is bacteria. Serratia marcescens strain MBC1 is a collection in the Microbiology Laboratory of the Department of Biology, Faculty of Mathematics and Natural Sciences, University of Lampung which enzymatic activities haven't been known yet. This research aimed to determine the enzymatic activity of $S$. marcesescens strain $\mathrm{MBC} 1$ that can be used as a candidate for biocontrol agents, biosurfactant producers, industry, or in the health sector. The screening was carried out using a qualitative method plate assay using selective solid media for each test, with three replications for each test. The data obtained were analyzed statistically using non-parametric Kruskall Wallis test. The lipolytic activity of the $S$. marcescens strain $\mathrm{MBC} 1$ showed high efficacy with an enzymatic index of 5.52 and amylase, cellulases, protease, mannanase, and chitinase with enzymatic indexes, respectively, 4.17, 1.50, $0.69,0.35$, and 0.27 . This enzyme activity of this isolate can be used as a candidate for biological control agents, biosurfactant producers, industry, or the health sector.
\end{abstract}

How to cite: Putri, M.H., Handayani, K., Setiawan, W.A., Damayanti, B., Ratih, C.L., \& Arifiyanto, A. (2021). Screening of Extracellular Enzymes on Serratia marcescens strain MBC1. Jurnal Riset Biologi dan Aplikasinya, 3(1): 23-29.

DOI: https://doi.org/10.26740/jrba.v3n1.p23-29.

\section{INTRODUCTION}

Serratia marcescens is a gram-negative bacteria and a member of the Enterobacteriaceae family. This bacteria can be found in water, soil, insects, vertebral digestive, and plant surfaces (Kahrarian et al., 2019). S. marcescens strain NMRL 65 has enzymatic activity lipase and protease based on research conducted by Mohanram et al. (2020). Furthermore, the research on the activity of the cellulase and chitinase enzymes of $S$. marcescens was also reported by Cahyani et al. (2017) and Tubkanlu et al. (2019).

According to their ability to catalyze a reaction, enzymes can be divided into several groups. One group of enzymes that can catalyze hydrolysis reactions is known as hydrolase enzymes (Wardoyo \& Aprilia, 2018). Hydrolase enzymes have an essential role in various reactions in living cells as a catalyst. Hydrolase enzymes can be used to break chemical bonds with water and break down organic substrates into simpler molecules (Wijaya et al., 2017). Cellulases, amylases, proteases, mannanases, and glycosidases were over hydrolase groups. These enzymes will hydrolyze polysaccharides into monosaccharides (Puspadewi et al., 2018).

In biotechnology, lipase is involved in fatdigesting supplements (Mohanasrinivasan et al., 2018). Moreover, the amylase enzymes can catalyze cereal foods such as wheat and bread (Padmavathi et al., 2018). The extracellular enzymes produced by microorganisms contributed to agriculture sectors, and industrial interests (Mohanasrinivasan et al., 2018; Susilowati et al., 2018).

Natural enzymes were outweighed because of safety and also eco-friendly. One of the enzyme producers is bacteria. Several bacteria that are 
capable of producing various types of enzymes are Bacillus licheniformis, Aspergillus sp. (Wijaya et al., 2017) Serratia marcescens (Cahyani et al., 2017) Acinetobacter sp., and Pseudomonas sp. (Puspadewi et al., 2018).

$S$. marcescens is one of the bacteria with enzymatic capabilities to produce several types of enzymes. S. marcescens strain MBC1 is one of the bacteria culture collection in the Microbiology Laboratory of FMIPA, the University of Lampung which was isolated from the agar media contaminated by Droshophila sp. and the enzymatic activities haven't been known yet. Therefore, this research to determine the enzymatic activity of $S$. marcesescens strain $\mathrm{MBC} 1$ that can be used as a candidate for biocontrol agents, biosurfactant producers, industry, or in the health sector.

\section{MATERIALS AND METHODS}

\section{S. marcescens strain $\mathrm{MBC1}$ Bacterial Isolate Culture}

Tryptic Soy Agar(TSA) medium was used to culture the bacteria $1.5 \mathrm{~g}$ of TSA was dissolved in $100 \mathrm{~mL}$ distilled water. The medium was sterilized at autoclave for 15 minutes. $S$. marcescens bacterial isolate strain MBC1 was cultured on TSA using a streak plate technique and then incubated at room temperature for 24-48 hours.

\section{Gram Staining}

One loop of Serratia marcescens strain MBC1 was added to an object-glass. The smear was stained with crystal violet for one minute. Then, it was washed under running water and Gram's iodine was added for one minute after that was exposed to acetone for decolorization. Then, as a counterstain, dilute safranin was applied and washed after 30 seconds. The Gram reaction and morphology were observed microscopically with the help of oil immersion objective after the bacteria was dried.

\section{KOH String Test}

A loopful of a bacterial colony from the culture plate was emulsified over a glass slide in $3 \% \mathrm{KOH}$. The suspension was stirred continuously for one minute and then the loop was gently pulled up from it. If the loop lift was sticky within the first 30 seconds of mixing in $\mathrm{KOH}$ solution, the result was considered positive.

\section{Enzymatic Activity}

Enzymatic activity tests were conducted using qualitative methods with solid fermented agar media. Three replications were taken place for each test.

Lipolytic activity tests were conducted based on the method used by Ervina et al. (2020) with modifications. This test uses Nutrient Agar (NA), 1\% of olive oil, $0.04 \%$ of methyl red, and $0.6 \%$ tween- 80 . A total of one loop of $S$. marcescens strain MBC1 was grown on the medium using the point method. Then the media was incubated at room temperature for 24-48 hours Lipolytic activity was characterized by the formation of a clear zone around the bacterial colony.

The proteolytic activity test was conducted based on a modified form of Pratika et al. (2021). The media composition consisted of Nutrient $\operatorname{Agar}(\mathrm{NA})$ and 1\% skim milk. One loop of the $S$. marcescens strain $\mathrm{MBC} 1$ isolate was taken and at a point on the medium. Then the media was incubated at room temperature for 24-48 hours. Positive proteolytic activity had indicated by a clear zone around the bacterial colony on the media's surface.

The amylolytic activity test was conducted based on Artha et al. (2019) with modifications using NA media supplemented with $1 \%$ starch. $S$. marcescens strain MBC1 was grown on solid media by point method and incubated at room temperature for 24-48 hours. Lugol iodine 1\% was poured into the culture to observe the clear zone for identification of amylase activity. A clear zone around the bacterial colony was a positive sign of amylase.

The chitinolytic activity tests were conducted based on Rosa et al. (2020) by using NA that was supplemented with $1 \%$ of colloidal chitin media. Then the media was incubated at room temperature for 24-48 hours. Colloidal chitin was made by dissolving $5 \mathrm{~g}$ of chitin powder in $80 \mathrm{ml}$ of concentrated $\mathrm{HCl}$ solution for 30 minutes by a magnetic stirrer and left 24 hours at $4 \circ \mathrm{C}$. The mixture was filtered using glass wool. The filtrate obtained was added with $40 \mathrm{ml}$ of cold distilled water and homogenized using a magnetic stirrer. Then, the filtrate adjusted to the $\mathrm{pH}$. Then it was centrifuged at $7,500 \mathrm{rpm}$ for 15 minutes. The filtrate obtained was separated from the supernatant and added with cold distilled water and centrifuged at $7500 \mathrm{rpm}$ for 15 minutes. The filtrate obtained is colloidal chitin which is ready for use. The clear zone was visualized with $0.1 \%$ congo red staining and rinsed using $1 \mathrm{M} \mathrm{NaCl}$.

The cellulose degradation was captured using the method used by Artha et al. (2019). The media composition consisted of 1\% Nutrient Agar (NA) and 
CMC media. One loop of S. marcescens strain MBC1 was inoculated on the media and incubated at room temperature for 24-48 hours. Congo red solution was poured into the culture to observe the clear zone was cellulolytic activity.

The mannanolytic activity was approached by the method of Sumardi (2005). The media was into two layers. The lower layer medium consisted of yeast extract $0.35 \%$, tryptone $0.35 \%$, $\mathrm{MgSO} 4$ $0.03 \%, \mathrm{KH}_{2} \mathrm{PO} 40.245 \%$, ammonium sulfate $0.25 \%$ and $\mathrm{NaCl}, 0.2 \%$. While the composition of the top layer media consisted of $0.03 \% \mathrm{MgSO} 4,0.245 \%$ $\mathrm{KH}_{2} \mathrm{PO} 4,0.25 \%$ ammonium sulfate, $0.2 \% \mathrm{NaCl}$ and $0.35 \%$ locust bean gum (LBG). S. marcescens strain MBC1 was spotted on the medium. Then, incubated at room temperature for 24-48 hours. The plate was stained with $0.5 \%$ congo red for 15 minutes and then rinsed with $1 \mathrm{M} \mathrm{NaCl}$ to observe mannanolytic activity in the presence of a clear zone. The determination of enzymatic index calculated using the formula according to the method used by Rosa et al (2020). The enzymatic index determination of the results can be calculated using the following formula by Rosa et al (2020).

Enzymatic index $=\frac{\text { Diameter of clear zone }- \text { Diameter of Colony }}{\text { Diameter of Colony }}$

The enzymes activity were analyzed using the non-parametric test of Kruskall Wallis with a significance level of $95 \%$.

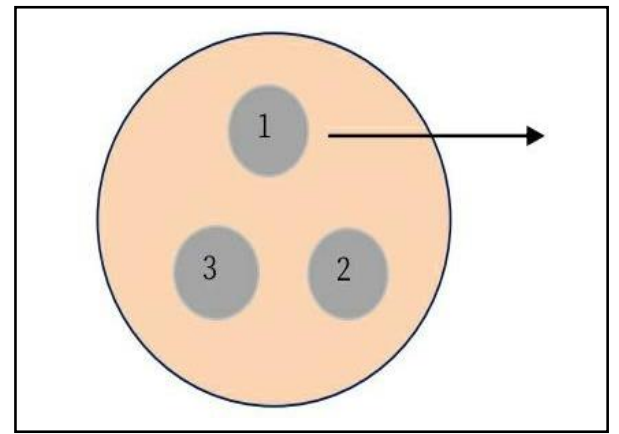

Figure 1. Measurement of clear zone $\mathrm{AB}, \mathrm{CD}, \mathrm{EF}$

ab, cd, ef

Average clear zone diameter $(\mathrm{Dz})$ Average colony diameter (Dk)

Average total clear zone diameter $(\mathrm{RDz})$

Average total colony diameter (RDk)

\section{RESULTS AND DISCUSSION}

The isolate has been identified as Serratia marcescens strain MBC1. It was a Gram-negative bacterium which had confirmed by $\mathrm{KOH} 3 \%$ test (Figure 2). From the gram staining, it can be seen that the bacteria are rounded (coccl) in shape with red color. The enzymatic ability had been calculated based on the colony compared to the clear zone diameter, to obtain the enzymatic index. $S$. marcescens strain $\mathrm{MBC} 1$ isolate has different enzymes activities (Figure 3).

Based on the research that has been done, cellulose concentration $1 \%$ was the optimum for the production of cellulase enzymes. The media used for testing the activity of the cellulase enzyme contains a carboxymethyl cellulose (CMC) substrate (Halimah et al., 2019). S. marcescens strain MBC1 isolate is known to have enzymatic activity because it can produce a clear zone amount $0.53 \mathrm{~mm}$ and is

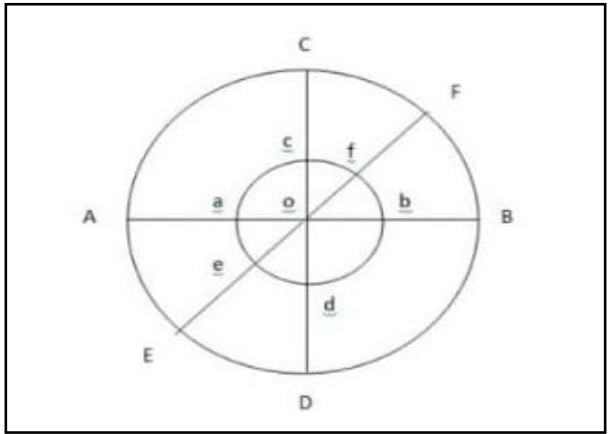

: Diameter of clear zone

: Colony diameter

$: \mathrm{AB}+\mathrm{BC}+\mathrm{CD} / 3$

$: \mathrm{ab}+\mathrm{bc}+\mathrm{cd} / 3$

$: \mathrm{Dz} 1+\mathrm{Dz} 2+\mathrm{Dz} 3 / 3$

$: \mathrm{Dk} 1+\mathrm{Dk} 2+\mathrm{Dk} 3 / 3$

classified as cellulolytic bacteria. Based on research by Cahyani et al. (2017) S. marcescens has cellulase enzyme activity. The utilization of cellulose has been conducted in various fields, including for the production of paper, fiber, and chemical derivatives plastics, and photographic film.

$S$. marcescens strain $\mathrm{MBC} 1$ isolate was able to degrade lipase-selective media by showing the hydrolysis zone around the colony by having a clear zone of $2.03 \mathrm{~mm}$. Based on the research by Istianah et al. (2019) if the ratio extracellular enzyme and activity index value is above 2 , it is included in the high extracellular ratio. In this method, the Tween80 substrate is used to detect lipase activity because it contains oleic acid esters, that can be hydrolyzed by the bacteria into mono oleic acid. This mono oleic acid will bind with calcium to form color cloudiness around the colony (Ervina et al., 2020). 


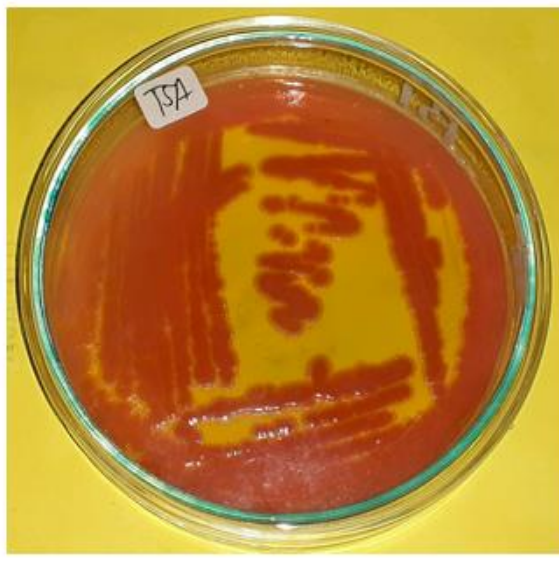

(a)

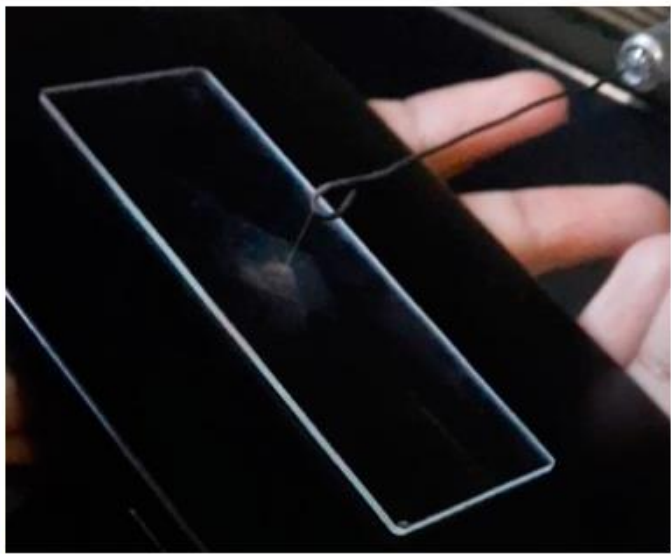

(b)

Figure 2. a) Macroscopic S. marcescens strain MBC1 b) KOH Test 3\%

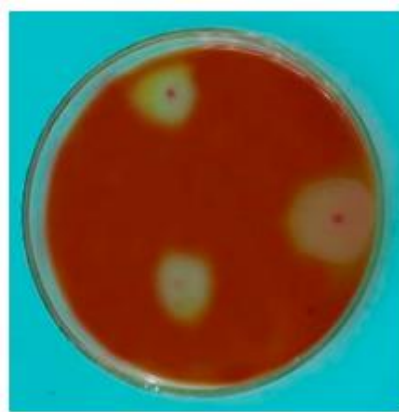

(a)

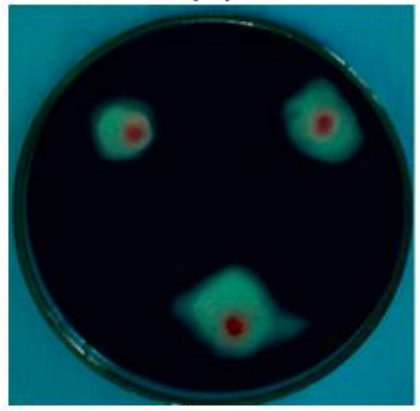

(d)

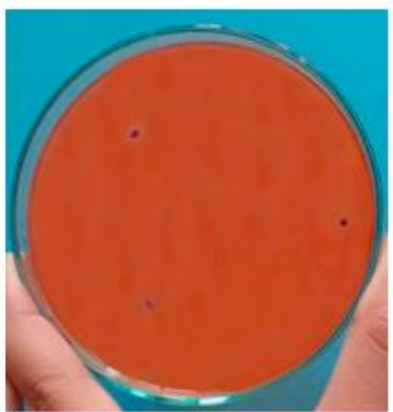

(b)

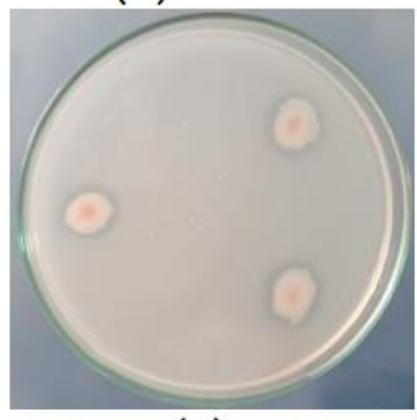

(e)

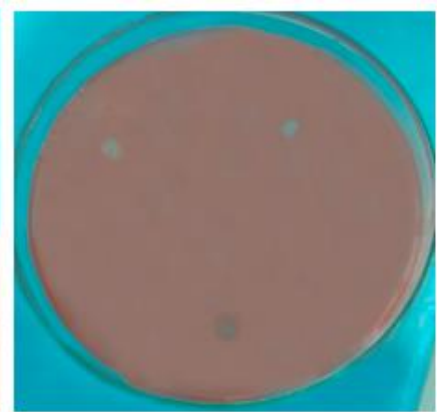

(c)

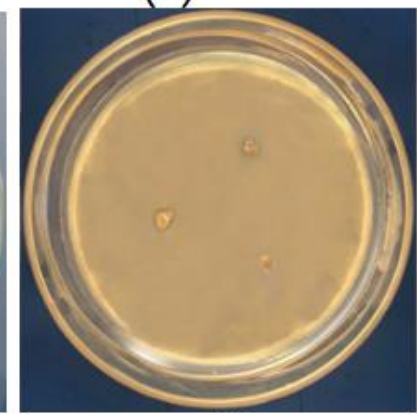

(f)

Figure 3. Clear zone on enzyme activity a) Lipase, b) Mannanase, c) Cellulase, d) Amylase, e) Chitinase, f) Protease

In the amylase enzyme activity, an isolate of $S$. marcescens strain MBC1 was cultured on a medium containing $1 \%$ starch substrate. The amylolytic ability was characterized by the formation of a clear zone in bacterial isolates after $0.1 \mathrm{M}$ iodine was dropped (Arfah et al., 2020). S. marcescens can produce amylase enzyme with form clear zone. The clear zone was formed because starch has been hydrolyzed to glucose, hence iodine did not absorb in the spiral flow of starch (amylose), whereas the blue color occurs due to the presence of iodine molecules entering the spiral stream of starch (amylose).

Chitin is a polymer that can be found in fungus and crustacea. The activity of the chitinase enzyme will be positive if it can produce a clear zone, this is caused by the isolate of $S$. marcescens strain $\mathrm{MBC} 1$ can break down the chitin in the medium (Linda et 
al., 2018). This is in line with research by Okay et al (2013) that used $S$. marcescens strain MO-1 grown on NA plates containing chitin and its chitinase activity was shown via the formation of a clear zone due to chitin degradation. This character will advantage to inhibit fungus and degraded chitin enriched materials.

The ability of the $S$. marcescens strain MBC1 to produce protease was characterized by the formation of a clear zone around the colony on the media with a clear zone of $0.6 \mathrm{~mm}$, as a sign that the bacteria are producing protease to hydrolyze peptone and skim milk by producing protease. The protein contained in the media is a protease inducer. The clear zone was an indicator of the presence of these bacterial isolates being able to utilize protein in the media as a source of nutrition (Pratika et al., 2021). This was in line with studies performed by (Mohanram et al., 2020). Using $S$. marcescens strain NMRL 65 hydrolyzed casein in skimmed milk agar producing a clear zone around colonies after 48 hours, which indicated the protease enzyme production.

The ability of the $S$. marcescens strain MBC1 to produce protease is characterized by the formation of a clear zone around the colony on the media with a clear zone of $0.6 \mathrm{~mm}$, as a sign that the bacteria was producing protease to hydrolyze peptone and skim milk by producing protease. The protein contained in the media is a protease inducer. The clear zone is an indicator of the presence of these bacterial isolates being able to utilize protein in the media as a source of nutrition (Pratika et al., 2021). This is in line with studies performed by (Mohanram et al., 2020) Using S. marcescens strain NMRL 65 hydrolyzed casein in skimmed milk agar producing a clear zone around colonies after 48 hours which indicated the protease enzyme production.

$S$. marcescens strain MBC1 showed the growth on a substrate containing locust bean gum (LBG) the size of the clear zone is $0.44 \mathrm{~mm}$. This is in line with studies performed by Olaniyi \& Arotupin (2013) that $S$. marcescens has mannanase activity and has shown the highest ratio of the clear zone to the colony. It by determiner of a clear zone that forms around the bacterial colony after being incubated. LBG which is present in the media is broken down by bacteria as a source of carbon in the metabolic process. This is because bacteria can break down galactomannan with the help of the $\beta$-mannanase enzyme complex reaction which produces mannose and mano-oligosaccharides (Sumardi, 2005). The enzyme activities of the $S$. marcescens strain MBC1 showed in Table 2. The enzymes activity were analyzed using the non-parametric method of Kruskall Wallis with a significance level of $95 \%$. The results showed that $S$. marcescens strain MBC1 had the highest index value on lipase and amylase activity of 5.52 and 4.17 .

Table 2. Results of Kruskal-Wallis Enzyme Test Statistic

\begin{tabular}{cccc}
\hline Enzymes & $\begin{array}{c}\text { Average of Colony } \\
(\mathbf{m m})\end{array}$ & Average of Clear Zone (mm) & Enzymatic Index \\
\hline Lipase & $0.33 \pm 0.11$ & $2.03 \pm 0.32$ & 5.52 \\
Amylase & $0.34 \pm 0.08$ & $1.79 \pm 0.68$ & 4.17 \\
Cellulase & $0.33 \pm 0.05$ & $0.53 \pm 0.05$ & 1.50 \\
Chitinase & $1.27 \pm 0.15$ & $1.6 \pm 0.1$ & 0.27 \\
Mannanase & $0.73 \pm 0.05$ & $0.44 \pm 0.05$ & 0.35 \\
Protease & $0.37 \pm 0.05$ & $0.6 \pm 0.1$ & 0.69 \\
\hline sig Kruskal & 0.162 & 0.011 & 0.025 \\
Wallis & & & \\
\hline
\end{tabular}

Enzyme activity was influenced by $\mathrm{pH}$, temperature, and substrate. Enzymes have an active site that compatible with the substrate. Hence, they can form the appropriate substrate enzymes with maximum results. On the other hand, unoptimized conditions related to $\mathrm{pH}$ and temperature conditions influenced conformational change on the enzyme, or even losing its activity (Irdawati et al., 2020).

S. marcescens strain $\mathrm{MBC} 1$ can produce the hydrolase enzyme, it can be used based on the needs. Lipase activity had potentially developed 
for biosurfactant production. Indeed, it often became a preliminary test to determine biosurfactant activity (Arifiyanto et al., 2017). The amylase activity also can catalyze cereal foods such as wheat and bread (Padmavathi et al., 2018). Besides, utilization of cellulase, amylase, and protease enzymes can be utilized in agriculture, industry, marine, and other sectors (Arifiyanto et al., 2017).

\section{CONCLUSION}

Based on the results, it can be concluded that $S$. marcescens strain MBC1 exhibits lipase, amylase, cellulase, protease, mannanase, and chitinase activities with the enzymatic index 5.52, 4.17, $1.50,0.69,0.35$, and 0.27 . This enzyme activity of this isolate can be used as a candidate for biological control agents, and is used in biosurfactant producers, industry, or the health sector

\section{ACKNOWLEDGEMENT}

The authors thank to Ms. Oni Mastuti as a laboratory assistant, who had helped in the process.

\section{REFERENCES}

Arfah, R. A., Lestari, Y. A., Dali, S., Muliadi, \& Liestianty, D. (2020). The Isolation of Termofil Amilolitik Bacterium and Activity Test of Harsh Extract Amylase Enzyme from the Hot Spring at Jailolo Bay in North Maluku. Journal of Physics: Conference Series, 1569(4). $\quad$ https://doi.org/10.1088/17426596/1569/4/042050.

Arifiyanto, A., Apriyanti, F. D., Purwaningsih, P., Kalqutny, S. H., Agustina, D., Surtiningsih, T., Shovitri, M., \& Zulaika, E. (2017). Lead (Pb) Bioaccumulation; Genera Bacillus Isolate $\mathrm{S} 1$ and SS19 as a Case Study. AIP Conference Proceedings, 1854(1). https://doi.org/10.1063/1.4985394.

Arifiyanto, A., Hapin, A., Meishy Handerlin, P., Berliana, D., \& Cindy, L. R. (2021). The biological prospective of red-pigmented bacteria cultured from contaminated agar media. Biodiversitas, 22(3), 11521159. https://doi.org/10.13057/biodiv/d220310.

Artha, O. A., Sudarno, H, P., \& L. A, S. (2019). Identification of Extracellular Enzyme-Producing Bacteria (Proteolytic, Cellulolytic, and Amylolytic) In The Sediment Of Extensive Ponds In Tanggulrejo, Gresik. IOP Conference Series: Earth and Environmental Science, 236(1). https://doi.org/10.1088/1755-1315/236/1/012003.

Cahyani, P., Wijanarka, \& Budi, R. (2017). Aktivitas Spesifik Selulase Serratia Marcescens Dengan Variasi Konsentrasi Amonium Sulfat ((Nh4)2So4) dan Ph. Jurnal Biologi, 6(2), 41-49. Retrieved from https://ejournal3.undip.ac.id/index.php/biologi/art icle/view/19535.

Ervina, E., Ekowati, C. N., Sumardi, \& Emantis, R. (2020). Lipolytic-screening of Bacillus genera as Biocontrol candidate In Coffee Plantation. Jurnal Ilmiah Biologi Eksperimen dan Keanekaragaman Hayati, 7(1), 31-34. http://dx.doi.org/10.23960\%2Fj_bekh.v7i1.2496.

Halimah, N., Baktir, \& Purkan, P. (2019). Exploration of Cellulolytic Microorganism as A Biocatalyst Candidate for Liquid Fertilizer Production. IOP Conference Series: Earth and Environmental Science, 217(1). Retrieved from https://iopscience.iop.org/article/10.1088/17551315/217/1/012021/meta.

Irdawati, Putri, N. D., Syamsuardi, Agustien, A., \& Rilda, Y. (2020). Potential of Xylanase Thermophilic Bacteria in the Pulp Biobleaching Process. ICoBioSE 2019, $10, \quad 23-27$. https://doi.org/10.2991/absr.k.200807.006.

Isti'anah, D., Ulfah, U., \& Ahmad, B. (2019). Karakterisasi Enzim Amilase dari Bakteri Bacillus megaterium pada Variasi Suhu, pH dan Konsentrasi Substrat. Jurnal Riset Biologi dan Aplikasinya, 1(2), 18-25. http://dx.doi.org/10.26740/jrba.v2n1.p11-17.

Kahrarian, Z., Saeed, K., \& Ahmad, T. (2019). A Review of the Production of Biosurfactant and Pigmented Prodigyosin by Bacteria Serrassia marsseñes. Asian Journal of Research in Medicine and Medical Science, $1(1), 18-24$.

Linda, T. M., Siregar, S., Fitri, W. D., Martina, A., Lestari, W., Roslim, D. I., \& Hapsoh. (2018). Isolation and screening of culturable endophytic bacteria from leaf of rubber plant that produces of chitinase. Journal of Physics: $\quad$ Conference Series, $1116(5)$. https://doi.org/10.1088/17426596/1116/5/05203 $\underline{8}$.

Mohanasrinivasan, V., C. Subathra, D., D., J., E., S., \& S. Jemimah, N. (2018). Purification and Characterization of Extracellular Lipase from Serratia marcescens VITSD2. Proceedings of the National Academy of Sciences India Section B Biological Sciences, $\quad 88(1), \quad 373-381$. https://doi.org/10.1007/s40011-016-0763-6.

Mohanram, R., Murlidhar, J. M., \& Susan, T. (2020). Isolation, Identification and Molecular Characterization of Serratia Marcescens Strain Nmrl65 an Opportunistic Human Pathogen From the Spoiled Coconut. International Journal of Environment and Health Sciences, 2(2), 81-86. https://doi.org/10.47062/1190.0202.02.

Okay, S., Özdal, M., \& Kurbanoğlu, E. B. (2013). Characterization, Antifungal activity, and Cell immobilization of a Chitinase from Serratia marcescens MO-1. Turkish Journal of Biology, 37(6), 639-644. https://doi.org/10.3906/biy-1208-45.

Olaniyi, O., \& Arotupin, D. (2013). Isolation and Screening of Mannanase Producing Bacteria from Agricultural Wastes. British Microbiology Research Journal, 3(4), 654-663.https://doi.org/10.9734/bmrj/2013/4221.

Padmavathi, T., Rayavarapu, B., Purushothama, R. P., Niranjan, N. R., \& Pavitra, P. V. (2018). Screening of Potential Probiotic Lactic Acid Bacteria And Production of Amylase and Its Partial Purification. Journal of Genetic Engineering and Biotechnology, $16(2)$, 357-362. https://doi.org/10.1016/i.jgeb.2018.03.005.

Pratika, M., M, A., \& Suwastika. (2021). Protease Activity From Bacterial Isolates of Nepenthes maxima reinw. ex nees. Journal of Physics: Conference Series, 1763(1), 0 12092.https://doi.org/10.1088/17426596/1763/1 /012092. 
Puspadewi, R., Putranti, A., Mira, A., \& Helma, K. (2018). Aktivitas Ekstraseluler yang Berasal dari Cladosporium tenuissimum. Seminar Nasional Farmasi (SNIFA) 4 UNJANI, 125- 132.

Rosa, E., C.N, E., Tundjung Tripeni, H., Ahmad, I., Ferly, A., \& Achmad, A. (2020). Characterization of Entomopathogenic Fungi as A Natural Biological Control Of American Cockroaches (Periplaneta americana). Biodiversitas, 21(11), 5276-5282. https://doi.org/10.13057/biodiv/d211131.

Sumardi. (2005). Optimasi Produksi Enzim $\beta$-Mananase Ekstraseluler dari Bakteri Geobacillus stearothermophilus L-07. Jurnal Sains Teknologi, 11(2), 66-71.

Susilowati, D. N., Indah, S., Kristina Dwi, A., \& Erny, Y. (2018). Penapisan Kapang Asal Lahan Sulfat Masam Kalimantan Selatan Sebagai Penghasil Enzim Ekstraseluler. Ilmu Pertanian, 1(21), 65-82. https://doi.org/10.24246/agric.2020.v32.i1.p65-82.

Tubkanlu, E., Aminzadeh, Karkhane, Alikhajeh, \&
Ghoroghi. (2019). Serratia marcescens B4A Chitinase Thermostability Enhancement by S390I QuikChange Site Directed Mutagenesis. Iranian Journal of Fisheries Sciences, 18(4), 1046-1059. https://doi.org/10.22092/ijfs.2019.119292.

Wardoyo, F. A., \& Aprilia, I. K. (2018). Peningkatan Stabilitas Termal dan Stabilitas Penggunaan Berulang Enzim Lipase Melalui Imobilisasi Pada Zeolit Alam. Jurnal Labora Medika, 2(1), 1-5. Retrieved from https://jurnal.unimus.ac.id/index.php/JLabMed.

Wijaya, P. S., Sri, W \& Nur, A. (2017). Morfologi dan Karakterisasi Pertumbuhan Bakteri Asam Laktat (um 1.4a) dari Proses Fermentasi Wikau Maombo Untuk Studi Awal Produksi Enzim Amilase. Jurnal Sains dan Teknologi Pangan, 2(4), 657-663. http://dx.doi.org/10.33772/jstp.v2i5.3745. 